\title{
The impact of changes in terms of payment for sewage removal on WWTP valuation using the DCF method
}

\author{
Jacek Dziubek ${ }^{1, *}$, Aneta Dziubek $^{2}$ \\ ${ }^{1}$ Gelsenwasser Polska GmbH, Dresden, Germany \\ ${ }^{2}$ State Higher Vocational School (PWSZ) in Głogów, Poland
}

\begin{abstract}
The article describes selected changes in the Water Law and the Collective Water Supply and Collective Sewage Disposal Act and their possible impact on the valuation of wastewater treatment plants. The issue of company valuation using DCF method is presented. By applying this method, several variants of assessment of the impact of changes in the law on the value of the sewage treatment plant in Głogów are proposed.
\end{abstract}

\section{Introduction}

In 2017, two acts crucial for an important segment of environmental protection such as water and sewage management were amended. These are: Water Law [1] and the Act on Public Water Supply and Sewage Removal [2,3]. The new regulations significantly change the functioning of the sector and make privatization processes or public-private partnerships easier. In this situation, enterprises running wastewater treatment plants (WWTP) or their organized parts may become subject to commercial transactions. Hence the important role that the valuation methods will play. A method considered the most important today is the Discounted Cash Flows Method (DCF). The article calculates the effects of these changes on the valuation of a specific WWTP using the DCF method.

\section{Company valuation methods}

There are many methods of company valuation. The basis of valuation is the main criterion for the classification of particular groups according to company value. The most commonly distinguished are four methods [4,5]. These are: property, income, market comparisons, and mixed methods. The variety of valuation methods contributes to the problem of choosing the proper one [6].

Property methods of company valuation [4,5] belong to the oldest and simplest valuation methods. They are based on publicly available and easily verifiable information (e.g. financial statements, balance sheet, statistical data). Calculations are made using relatively simple methods and results are unambiguous.

\footnotetext{
*Corresponding author: jacek.dziubek@gelsenwasser.p1
} 
Due to the relative simplicity and asset unambiguity of the valuation strategy, it is a reference point for other methods, e.g. income-based ones.

Profit methods of company valuation [4,5] combine the value of a company with the income it generates. Such an approach can be justified by the fact that for investors seeking to acquire an enterprise it is interesting to know what profits they can expect in the future. Therefore, the value of the company is the current expected value of its future income. In addition, this effect may be augmented by synergy effects including, for example, an increase in the market position or scale effect. There are a number of income methods for the valuation of enterprises based on the discounted income stream and their variations $[4,5]$. The DCF method is the most commonly used one. This method distinguishes:

- Free Cash Flow to Equity (FCFE) a variant of the discounted cash flow model belonging to shareholders,

- Free Cash Flow to Firm (FCFF) a variant of the discounted cash flow model belonging to investors.

This method is widespread [7] and will be discussed in greater detail in Chapter 3.

\section{Company valuation using DCF}

The company's fixed assets are not the only element contributing to its value. From the investor's point of view, its ability to generate income is much more important. More precisely, in the income approach [8], the value of the enterprise is the current value of the expected future income.

Such a description of valuation method immediately suggests the existence of a variety of its variants depending mainly on the method of future income forecasting, value of equity, type of income on which the calculation is based, etc.

In its most basic form, the formula can be expressed as follows [5]:

where:

$$
V=\frac{C F_{1}}{(1+k)^{1}}+\frac{C F_{2}}{(1+k)^{2}}+\frac{C F_{3}}{(1+k)^{3}}+\cdots+\frac{C F_{n}}{(1+k)^{n}}+\frac{R V}{(1+k)^{n}}
$$

$\mathrm{V}$-value of company based on DCF

$\mathrm{CF}_{\mathrm{i}}$ - cash flow in a period

k-discount rate

n-number years in the forecast

$\mathrm{RV}$ - residual value of the company $=\mathrm{CF}_{\mathrm{n}} \mathrm{x}(1-\mathrm{g}) /($ WACC-g)

g-fixed rate of cash flow growth after the forecast period

WACC $($ Weighted Average Cost of Capital $)=$ share of equity $*$ cost of equity + share of foreign capital * cost of foreign capital * $(1$ - income tax $)$

The FCFF is calculated:

+ EBIT * (1- income tax),

+ depreciation,

+ changes in net working capital,

- investment expenditure.

On the basis of formula (1), the value of WWTP will be calculated in Chapter 5.

\section{New legal regulations}

The new Water Law Act [1] came into force on January 1, 2018, amending the act of 2001. It introduces a number of changes in relation to the existing regulation. It ought to fully implement the regulations of The Water Framework Directive [9], including its Article 
9 which refers to the reimbursement of costs for water services. Poland has already been reprimanded by the European Commission for failing to implement these regulations.

One of the significant changes is the establishment of the National Council of Water Management „Polskie Wody" from January 1, 2018. When it comes to the method of determining tariffs, a very important competence that this agency has is as being a market regulator. This is where all applications for suggested tariffs, including prices for water supply and sewage collection, will be sent. From this year, the regulator will pronounce judgement on draft water and sewage removal terms and conditions, approve tariffs for public water supply and collective sewage removal and resolve disputes between water-supply and sewage removal companies and customers. It is worth noting that previously the functions of the regulator were held by the commune head, mayor or city president.

Another important change is the amendment to the Act on public water supply and sewage removal $[2,3]$. It imposes on enterprises the obligation to develop new water supply terms and conditions and also extends - from one year to three years - the period for which tariff applications with regard to water and sewage are prepared.

The consequence of the above amendment coming into force is the announcement of a new regulation on the determination of tariffs, the application form for the approval of tariffs and the terms of settlements for public water supply and sewage removal [10]. It is worth taking a look at three of these regulations. These are entries that may significantly affect income of water and sewage companies. All of them are included in $\S 6$ of the Regulation. These are points: 1a), 5) and 6).

"§ 6 The water and sewage company determines the necessary revenue for the purpose of calculating tariff prices and fees planned for 3 years of tariff validity, taking into account in particular:

1) operating and maintenance costs incurred under the public water supply and sewage removal, including:

a) depreciation or amortization determined in accordance with the accounting rules from the initial value of fixed assets using the straight-line method, except for depreciation or depreciation of fixed assets created or acquired from a subsidy or subvention up to the subsidy or grant received,

...

5) repayment of principal installments over the value of depreciation or amortization, which was accepted for the calculation of the necessary revenues referred to in item 1 a, and the costs of acquiring own shares or stocks for the purpose of redemption or the costs of repayment of loans and credits taken out to finance such redemption;

6) reasonable profit margin" [10].

The ban on including the cost of fixed assets financed from EU funds into the tariffs described in $\S 6$ point 1 arises many doubts. Such ban leads to the decapitalization of the property. It directly lowers the value of the company and leads to a decrease in its value calculated by the DCF method.

Another provision that may bring similar effects when it comes to the value is the limitation of the acceptable level of profit margin for water and sewage companies (paragraph 6, point 5). In the original version of the project, it was limited to $5 \%$, now this value has to be validated.

An interesting point is point 5 . On the one hand, the possibility of including capital instalments over the depreciation value may, in some enterprises, mitigate the effects of the inability to qualify for tariff depreciation of funds financed by EU funds. On the other hand, it enables some capital changes in the company (sale of shares by the commune or taking up shares by a new partner in the raised capital) and then redemption of these shares by the company in order to extinguish them. 


\section{Impact of new legal regulations on value of WWTP}

This chapter calculates and compares value of WWTP using the DCF method for four variants:

Variant I - for the previous legal status,

Variant II - for the case where the profit margin is reduced to $5 \%$ and the whole depreciation is a tariff cost,

Variant III - for the case when the profit margin remains unchanged and a company cannot include part of the depreciation into tariff costs

Variant IV - for the case in which the profit margin is limited to $5 \%$ and a company cannot include part of the depreciation into tariff costs

\subsection{Wastewater treatment plant in Głogów}

WWTP in Głogów is located in the west part of the city. This WWTP is the only treatment plant in the agglomeration of Głogów, therefore it also serves several nearby villages. The area from which sewage flows to it is inhabited by about 75000 people and the treatment plant is prepared to remove contamination as for the amount of $100000 \mathrm{PE}$ (populationequivalent). The length of the sewerage network is $191 \mathrm{~km}$.

It is a mechanical-biological WWTP with in-depth removal of biogenic compounds. Periodically, the purification process can be supported by chemicals to remove phosphorus. Wastewater from the sewage treatment plant discharged to the receiver corresponds to the permits required by the Water Law Act [11], as well as the Regulation of the Minister of the Environment [12].

\subsection{Value of wastewater treatment plants}

Table 1 contains free cash flow and valuation of WWTP for variant I.

Table 1. Valuation of WWTP for variant I.

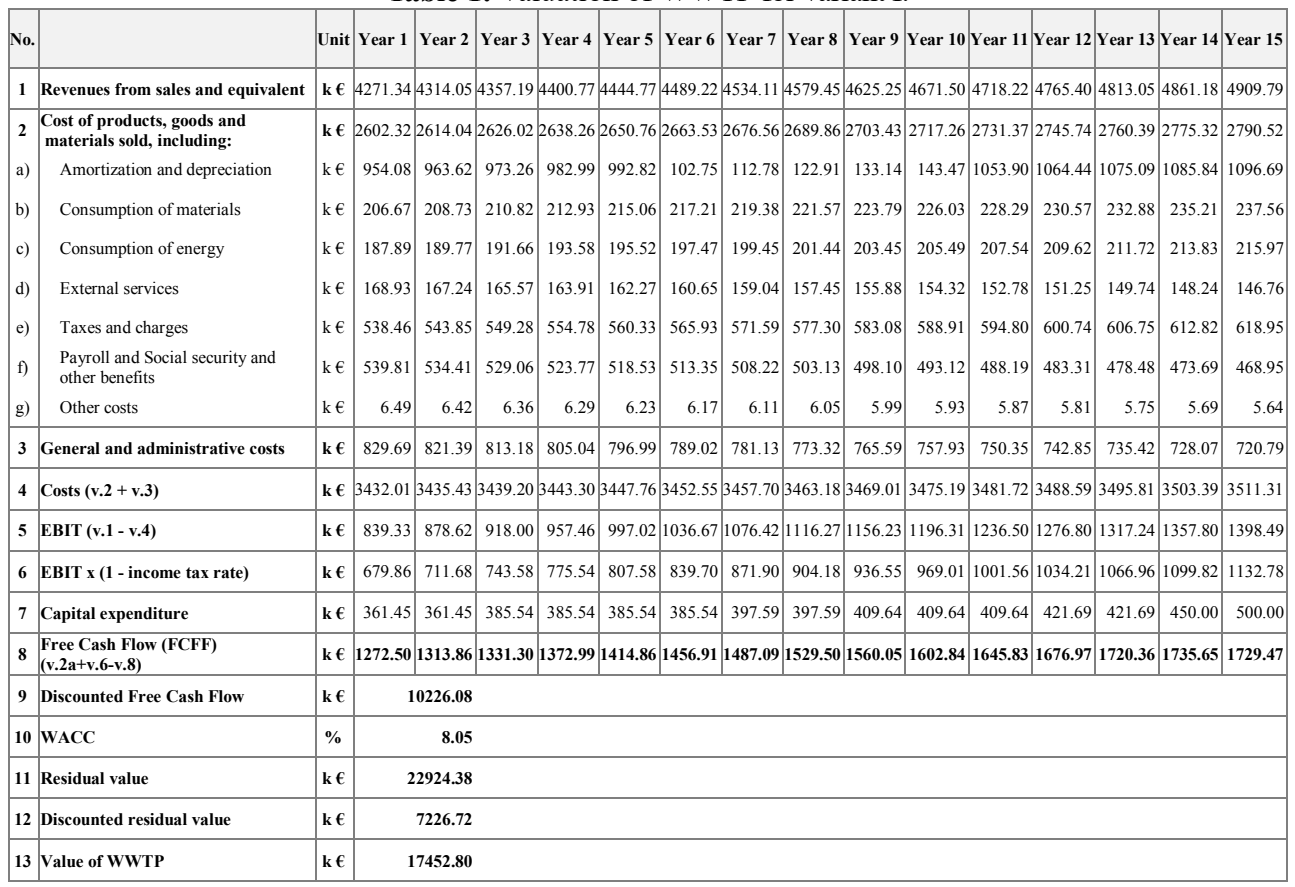


Table 2 contains free cash flow and valuation of WWTP for variant II.

Table 2. Valuation of WWTP for variant II.

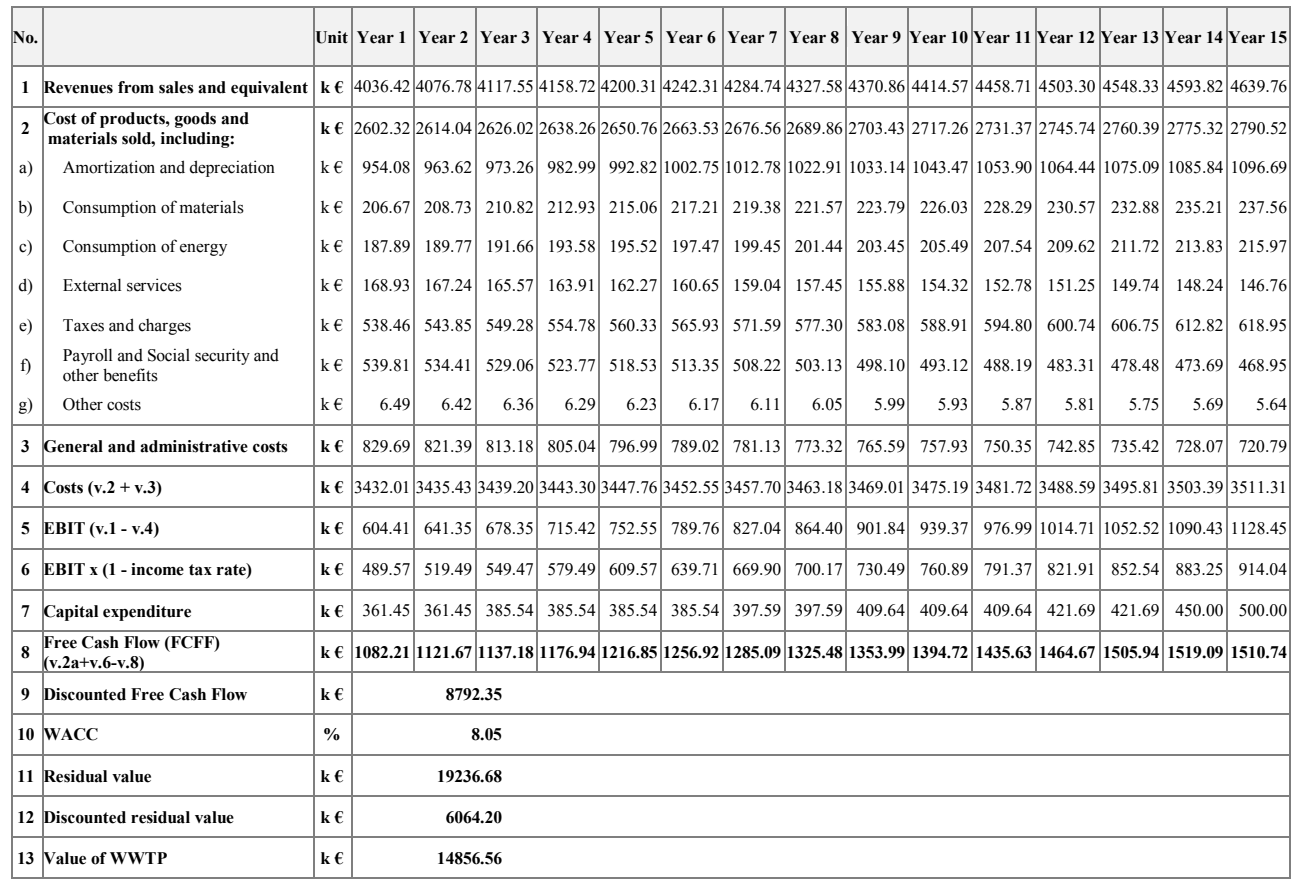

Table 3 contains free cash flow and valuation of WWTP for variant III.

Table 3. Valuation of WWTP for variant III.

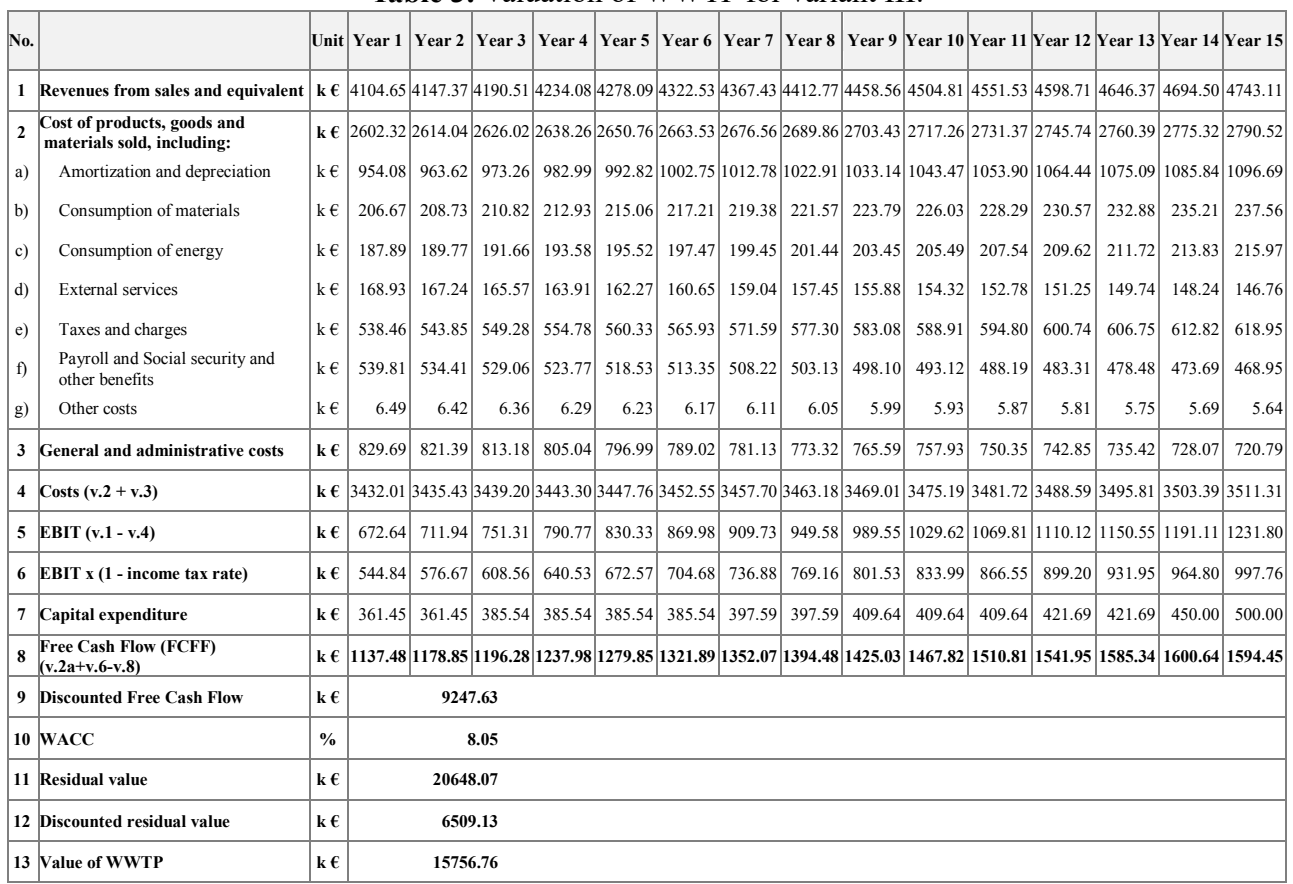


Table 4 contains free cash flow and valuation of WWTP for variant IV.

Table 4. Valuation of WWTP for variant IV.

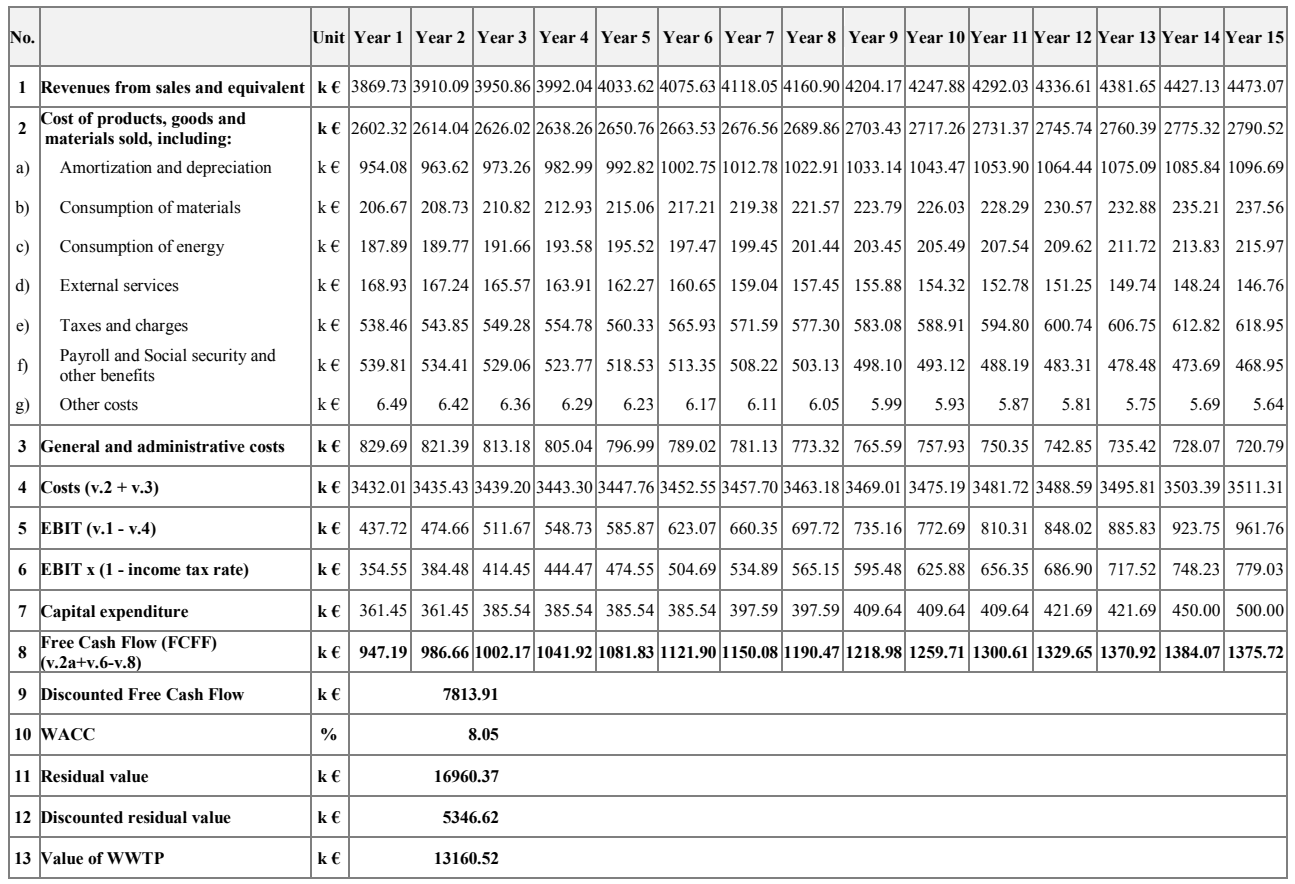

Table 5 summarizes basic information from tables 1- 4 which determine the value of WWTP in each variant. A change in the way of pricing will lower the value of WWTP, whereas in the case of the Głogów WWTP a lower profit margin would have a greater impact (decrease by ca. 15\%). than the possible lack of depreciation of estate built from EU funds (decrease by ca. 10\%). Of course, if both factors are taken into account, the decrease is the highest and increases to ca. $25 \%$.

Table 5. The values of WWTP calculated using the DCF method in variants 1- 4 .

\begin{tabular}{rcrrrrr}
\hline No. & Description & & Variant I & Variant II & Variant III & Variant IV \\
\hline 1 & Free Cash Flow to Firm & $\mathrm{k} €$ & 10226.08 & 8792.35 & 9247.63 & 7813.91 \\
\hline 2 & Residual Value & $\mathrm{k} €$ & 22924.38 & 19236.68 & 20648.07 & 16960.37 \\
\hline 3 & Discounted Residual Value & $\mathrm{k} €$ & 7226.72 & 6064.20 & 6509.13 & 5346.62 \\
\hline 4 & Value of WWTP & $\mathrm{k} €$ & 17452.80 & 14856.56 & 15756.76 & 13160.52 \\
\hline
\end{tabular}

Difference Between Variants

\begin{tabular}{rrr}
\hline I - II & I-III & I-IV \\
\hline 2596.24 & 1696.03 & 4292.28 \\
\hline $\mathbf{1 4 . 9 \%}$ & $\mathbf{9 . 7 \%}$ & $\mathbf{2 4 . 6 \%}$ \\
\hline
\end{tabular}




\section{Conclusions}

The issue of valuation of a company in recent years is becoming more important in the case of municipal enterprises. Valuation using DCF is a recognized and widely used method. Value of a company understood and calculated this way is its ability to generate free cash, a fundamental issue from the owners' point of view. What is important is the fact that this method emphasises the future, not past events, and financial flows, not Balance Sheet. Only real money means that the company is able to service its liabilities, including paying off debts, paying dividends or developing through investments.

The amendment of the most important legal acts regulating working of the water and sewage industry may lead to major changes in its functioning. In particular, it may result in the industry opening to external investors. At least two facts favour here. First of all, municipal authorities will no longer operate as a regulator of water and sewage industry, and municipal councils will not be responsible for approving tariffs. This may result in a significant depoliticisation of the approach to the shareholder structure. Secondly, in the tariff regulation ( $\$ 6$ point 5) there is an incentive for search for external investors by providing them with funding to remit shares which, for example, previously the municipality sold to entrepreneur.

Not taking depreciation of assets financed from subsidies into account may lead to the decapitalization of assets on the one hand and to a reduction of the value of the company on the other. It is also worth noting that such regulation places economic entities in an unequal situation. If one was carrying out investments with EU support alone, and the other was holding such assets, if the investor was a commune, their financial situations would be different. The other entrepreneur will be able to implement the entire lease costs into the tariff.

It is also important to change the regulations limiting the profit margin. With the currently proposed regulation, it is unclear who, and on what basis, will assess in what amount the profit margin is reasonable and acceptable.

The example of WWTP in Głogów shows that the introduction of the discussed regulations would contribute to a decrease of the value of this type of company.

\section{References}

1. Act $(2017.1566)$

2. Act (2017.2180)

3. Act (2017.328)

4. Dowżycki A., Sobolewski H., Tłuchowski W., Restrukturyzacja, prywatyzacja i wycena przedsiębiorstw, (WAE Poznań, 2004)

5. FIERLA A. Wycena przedsiębiorstwa metodami dochodowymi (SGH Warszawa, 2008)

6. Lipinski M. Contr. rach. zarz., 9,12-18, (2015)

7. Copeland T., Koller T., Murin J., Valuation: Measuring and Managing the Values of Companies, (John Wiley Sons, 2000)

8. Krzeszowski W.D. Zeszyty Naukowe Uniwersytetu Szczecińskiego, 1-9, (2015)

9. The Water Framework Directive (2000/60/EC)

10. Regulation (project from 31.02.2018)

11. Administrative decision No. SR.I.6811/130/07, unpublished

12. Regulation (2014.1800) 